\title{
New Hopes for Plasma-Based Cancer Treatment
}

\author{
Hiromasa Tanaka ${ }^{1, *(\mathbb{D}}$, Masaaki Mizuno ${ }^{2}$, Kenji Ishikawa ${ }^{3} \mathbb{D}$, Shinya Toyokuni ${ }^{4}$, \\ Hiroaki Kajiyama ${ }^{5}$, Fumitaka Kikkawa ${ }^{5}$ and Masaru Hori ${ }^{1}$ \\ 1 Institute of Innovation for Future Society, Nagoya University, Furo-cho, Chikusa-ku, \\ Nagoya 464-8603, Japan; hori@nuee.nagoya-u.ac.jp \\ 2 Center for Advanced Medicine and Clinical Research, Nagoya University Hospital, Tsurumai-cho 65, \\ Showa-ku, Nagoya 466-8550, Japan; mmizuno@med.nagoya-u.ac.jp \\ 3 Plasma Nanotechnology Research Center, Nagoya University, Furo-cho, Chikusa-ku, \\ Nagoya 464-8603, Japan; ishikawa@plasma.engg.nagoya-u.ac.jp \\ 4 Department of Pathology and Biological Responses, Nagoya University Graduate School of Medicine, \\ Tsurumai-cho 65, Showa-ku, Nagoya 466-8550, Japan; toyokuni@med.nagoya-u.ac.jp \\ 5 Department of Obstetrics and Gynecology, Nagoya University Graduate School of Medicine, \\ Tsurumai-cho 65, Showa-ku, Nagoya 466-8550, Japan; kajiyama@med.nagoya-u.ac.jp (H.K.); \\ kikkawaf@med.nagoya-u.ac.jp (F.K.) \\ * Correspondence: htanaka@plasma.engg.nagoya-u.ac.jp; Tel.: +81-52-788-6230
}

Received: 30 July 2018; Accepted: 16 August 2018; Published: 18 August 2018

\begin{abstract}
Non-thermal plasma represents a novel approach in cancer treatment. Both direct and indirect plasma treatments are available, with clinical trials of direct plasma treatment in progress. Indirect treatments involve chemotherapy (i.e., plasma-activated medium) and immunotherapy. Recent studies suggest that integrated plasma treatments could be an extremely effective approach to cancer therapy.
\end{abstract}

Keywords: plasma cancer treatment; plasma-activated medium (PAM); plasma-assisted immunotherapy

\section{Introduction}

Plasma-based cancer treatments represent a critical area in the field of plasma medicine [1-3]. Some pioneering in vitro [4] and in vivo [5] works have shown that non-thermal plasma exerts anti-tumor effects. Currently, two options for plasma cancer treatment are available: direct and indirect (Figure 1). Clinical trials of cancer treatments using non-thermal plasma (direct plasma treatments) are ongoing in Germany [6] and the USA [7]. Two different types of indirect plasma treatment have been proposed: plasma-assisted immunotherapy [8] and plasma-activated medium (PAM) $[9,10]$. Plasma is also considered as an adjuvant therapy, and the three main options are plasma in combination with chemotherapy [11,12], plasma to modulate tumor microenvironment [13,14], and plasma in association with electrotherapy [15]. These approaches have dramatically broadened the ways of using non-thermal plasma for treating cancers and other diseases.

Currently, two options for plasma cancer treatment are available: direct and indirect. Clinical trials of direct plasma treatments are ongoing. Indirect treatments include plasma-assisted cancer immunotherapy and plasma-activated medium (PAM) therapy. 


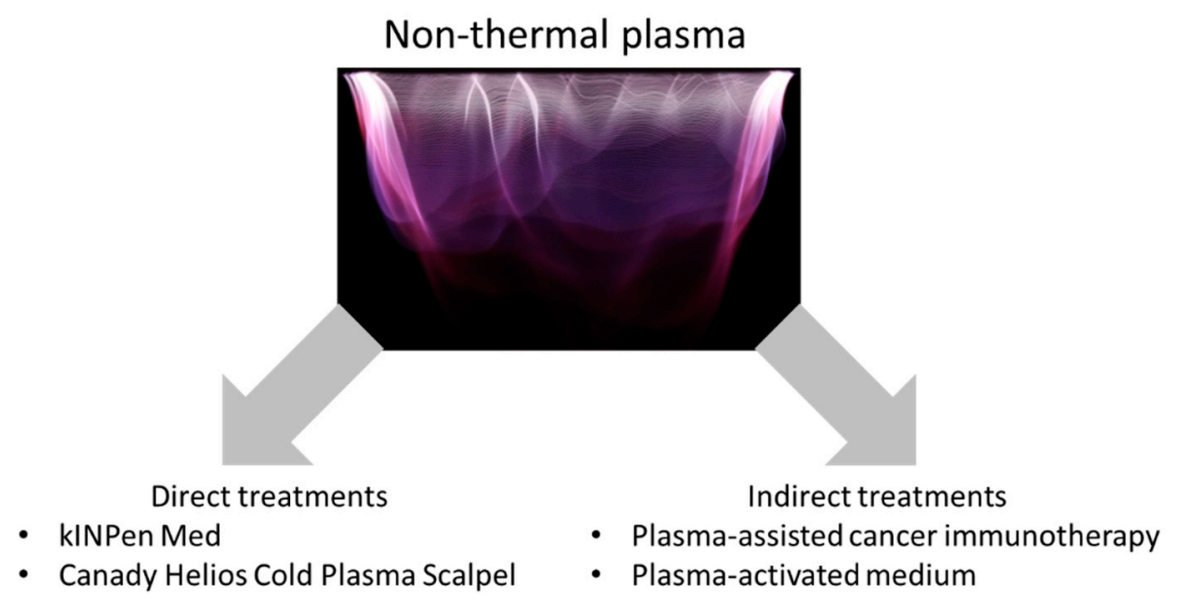

Figure 1. Two types of plasma-based cancer treatments.

\section{Direct Treatments}

Direct plasma treatments are the most straightforward. A variety of plasma sources have been developed for medical applications such as cancer treatment [16-20]. Metelmann et al. used a plasma source known as kINPen MED to treat advanced head and neck carcinoma ulcerations and patients in the final stages of disease [6,21]. Plasma treatment reduced both pain and odor. Only a few myeloid cells were present in tumor tissue of patients that received frequent plasma treatment, whereas numerous myeloid cells were found in tissue sections of patients that did not receive plasma treatment. Canady et al. treated liver cancer using a Canady Helios Cold Plasma Scalpel to remove cancerous tissue without damaging the blood supply to the remaining liver.

Since plasma needle was used for treatment of culture cells [22], various plasma sources have been developed for cancer treatment. The plasma jet and dielectric barrier discharge (DBD) have been developed and widely used in plasma cancer treatment. A pulsed DBD with microsecond pulses was used for treatment of xenograft model mouse of human glioblastoma cells [23]. Recently, nanosecond-pulsed plasma have been developed as potential tools in cancer treatment [24,25].

\section{Indirect Treatment: Plasma-Assisted Cancer Immunotherapy}

Several researchers have proposed the use of plasmas as immune modulators for treating cancer. The number of cells in the human body is estimated at about 40 trillion, and a small portion of these cells acquire mutations and become cancerous every day. However, the immune system typically removes mutated cells. It is only when cancerous cells avoid the immune system that cancerous disease develops. Recently, a variety of anti-cancer therapies designed to modulate the immune system have been developed [26-28]. These approaches include the use of cytokines, cell-based therapies, and immune checkpoint blockade. For example, the US Food and Drug Administration (FDA) approved the first cellular immunotherapy (sipuleucel-T) for prostate cancer in 2010 [29]. The FDA also approved the anti-PD1 monoclonal antibody, nivolumab, for adjuvant treatment of patients with melanoma involving the lymph nodes and patients with metastatic disease who have undergone complete resection [30].

A better understanding of the interactions between cancer cells and the immune system has increased interest in immunotherapies over the last decade [31,32]. Radiation and some chemotherapeutic drugs increase immunogenicity by triggering immunogenic cell death (ICD). Damaged or stressed cancer cells present "danger signals" known as damage-associated molecular pattern (DAMP) molecules. High-mobility group box 1, ATP, and calreticulin (CRT) are well-known DAMP molecules that are retained inside the cell in the healthy state and released only in response to stress or cell damage. Cancer cells usually induce immunosuppression; however, ICD-associated 
DAMP molecules can reactivate anti-cancer immunity by triggering dendritic cell maturation and antigen presentation.

Several recent studies have suggested that non-thermal plasma treatment induces ICD and stimulates macrophages [25,33-35]. Non-thermal plasma treatment was shown to stimulate extracellular ATP secretion and enhance cell death via ICD-mediated macrophage stimulation. Plasma-generated reactive oxygen species (ROS) are major effectors of ICD. Non-thermal plasma elicits surface exposure of CRT, and N-acetyl cysteine, which is an ROS scavenger, reduces the externalization of CRT. These results suggest that intracellular ROS are responsible for plasma-induced CRT production. Tumor necrosis factor-alpha released from plasma-activated macrophages induces tumor cell death [36].

In the future, non-thermal plasma will be used to induce ICD in tumors to help dendritic cells find, eat, and present cancer cell antigen to elicit robust $\mathrm{T}$ cell immune responses [37]. It was shown that naïve $T$ helper cells were less sensitive toward non-thermal plasma treatment, suggesting that plasma could be used as a tool to redox-control $\mathrm{T}$ cell phenotypes in cancer immunology [38]. Flow cytometric technique for microparticle characterization was established, and the number and size of microparticles released were shown to be modulated in THP-1 monocytes, polymorphonuclear leukocytes (PMN), and peripheral blood mononuclear cells (PBMC) after plasma exposure [39]. Interestingly, abscopal effects of non-thermal plasma treatment on tumor growth were observed, suggesting that plasma activated innate immune response [24].

\section{Indirect Treatment: PAM}

PAM has been proposed as a type of cancer chemotherapy. Various in vitro experiments have demonstrated that PAM exerts anti-tumor effects on many kinds of cancer cells $[9,10,40,41]$. In most cases, PAM induces intracellular ROS production and subsequent apoptosis of cancer cells. The mechanism through which PAM induces the apoptosis of cancer cells depends on the cell type [42,43]. In glioblastoma cells, down-regulation of survival and proliferation signaling networks plays a critical role in PAM-induced apoptosis $[9,42,44]$. Aquaporins, which transport hydrogen peroxide into the plasma membrane, are also key factors in apoptosis induction [45]. Many in vivo experiments have also demonstrated the anti-tumor effects of PAM against a variety of cancers. In a xenograft mouse model, PAM inhibited the growth of ovarian and pancreatic cancer tumor cells [10,41]. Intraperitoneal injection of PAM/plasma-activated Ringer's lactate (PAL) inhibited the metastasis of ovarian, gastric, and pancreatic cancer tumors in disease model mouse experiments examining peritoneal metastasis [46-48]. However, in apoptosis induced by PAL, less ROS are produced in comparison with PAM [49], suggesting that components generated in PAM control the redox balance.

\section{Conclusions}

Two major options are available for plasma-based cancer therapies: direct and indirect treatments. Direct plasma treatment methods have already been introduced clinically, whereas indirect plasma treatment methods such as plasma-assisted cancer immunotherapy and PAM therapy are new approaches currently under study. In the future, the overall survival of cancer patients could be significantly improved by combining direct and indirect plasma treatments.

Funding: This work was funded in part by Grants-in-Aid for Scientific Research on Innovative Areas "Plasma Medical Innovation" (No. 24108002 and No. 24108008), a Grant-in-Aid for Young Scientists (A) (No. 15H05430), a Grant-in-Aid for Challenging Exploratory Research Grant (No. 15K13390), and Grant-in-Aid for Scientific Research (C) (No. 18K03599) from the Ministry of Education, Culture, Sports, Science and Technology of Japan.

Conflicts of Interest: The authors declare no conflicts of interest. 


\section{References}

1. Laroussi, M. From killing bacteria to destroying cancer cells: 20 years of plasma medicine. Plasma Process. Polym. 2014, 11, 1138-1141. [CrossRef]

2. Tanaka, H.; Ishikawa, K.; Mizuno, M.; Toyokuni, S.; Kajiyama, H.; Kikkawa, F.; Metelmann, H.R.; Hori, M. State of the art in medical applications using non-thermal atmospheric pressure plasma. Rev. Mod. Plasma Phys. 2017, 1, 3. [CrossRef]

3. Schlegel, J.; Köritzer, J.; Boxhammer, V. Plasma in cancer treatment. Clin. Plasma Med. 2013, 1, 2-7. [CrossRef]

4. Stoffels, E.; Kieft, I.E.; Sladek, R.E.J.; van den Bedem, L.J.M.; van der Laan, E.P.; Steinbuch, M. Plasma needle for in vivo medical treatment: Recent developments and perspectives. Plasma Sources Sci. Technol. 2006, 15, S169-S180. [CrossRef]

5. Vandamme, M.; Robert, E.; Lerondel, S.; Sarron, V.; Ries, D.; Dozias, S.; Sobilo, J.; Gosset, D.; Kieda, C.; Legrain, B.; et al. Ros implication in a new antitumor strategy based on non-thermal plasma. Int. J. Cancer 2012, 130, 2185-2194. [CrossRef] [PubMed]

6. Metelmann, H.R.; Nedrelow, D.S.; Seebauer, C.; Schuster, M.; von Woedtke, T.; Weltmann, K.D.; Kindler, S.; Metelmann, P.H.; Finkelstein, S.E.; Von Hoff, D.D.; et al. Head and neck cancer treatment and physical plasma. Clin. Plasma Med. 2015, 3, 17-23. [CrossRef]

7. Shashurin, A.; Scott, D.; Zhuang, T.S.; Canady, J.; Beilis, I.I.; Keidar, M. Electric discharge during electrosurgery. Sci. Rep. 2015, 5, 9946. [CrossRef] [PubMed]

8. Miller, V.; Lin, A.; Fridman, G.; Dobrynin, D.; Fridman, A. Plasma stimulation of migration of macrophages. Plasma Process. Polym. 2014, 11, 1193-1197. [CrossRef]

9. Tanaka, H.; Mizuno, M.; Ishikawa, K.; Nakamura, K.; Kajiyama, H.; Kano, H.; Kikkawa, F.; Hori, M. Plasma-activated medium selectively kills glioblastoma brain tumor cells by down-regulating a survival signaling molecule, akt kinase. Plasma Med. 2013, 1, 265-277. [CrossRef]

10. Utsumi, F.; Kajiyama, H.; Nakamura, K.; Tanaka, H.; Mizuno, M.; Ishikawa, K.; Kondo, H.; Kano, H.; Hori, M.; Kikkawa, F. Effect of indirect nonequilibrium atmospheric pressure plasma on anti-proliferative activity against chronic chemo-resistant ovarian cancer cells in vitro and in vivo. PLoS ONE 2013, 8, e81576. [CrossRef] [PubMed]

11. Brulle, L.; Vandamme, M.; Ries, D.; Martel, E.; Robert, E.; Lerondel, S.; Trichet, V.; Richard, S.; Pouvesle, J.M.; Le Pape, A. Effects of a non thermal plasma treatment alone or in combination with gemcitabine in a MIA PaCa2-luc orthotopic pancreatic carcinoma model. PLoS ONE 2012, 7, e52653. [CrossRef] [PubMed]

12. Koritzer, J.; Boxhammer, V.; Schafer, A.; Shimizu, T.; Klampfl, T.G.; Li, Y.F.; Welz, C.; Schwenk-Zieger, S.; Morfill, G.E.; Zimmermann, J.L.; et al. Restoration of sensitivity in chemo-resistant glioma cells by cold atmospheric plasma. PLoS ONE 2013, 8, e64498. [CrossRef] [PubMed]

13. Collet, G.; Robert, E.; Lenoir, A.; Vandamme, M.; Darny, T.; Dozias, S.; Kieda, C.; Pouvesle, J.M. Plasma jet-induced tissue oxygenation: Potentialities for new therapeutic strategies. Plasma Sources Sci. Technol. 2014, 23, 012005. [CrossRef]

14. Kisch, T.; Schleusser, S.; Helmke, A.; Mauss, K.L.; Wenzel, E.T.; Hasemann, B.; Mailaender, P.; Kraemer, R. The repetitive use of non-thermal dielectric barrier discharge plasma boosts cutaneous microcirculatory effects. Microvasc. Res. 2016, 106, 8-13. [CrossRef] [PubMed]

15. Daeschlein, G.; Scholz, S.; Lutze, S.; Arnold, A.; von Podewils, S.; Kiefer, T.; Tueting, T.; Hardt, O.; Haase, H.; Grisk, O; et al. Comparison between cold plasma, electrochemotherapy and combined therapy in a melanoma mouse model. Exp. Dermatol. 2013, 22, 582-586. [CrossRef] [PubMed]

16. Fridman, G.; Friedman, G.; Gutsol, A.; Shekhter, A.B.; Vasilets, V.N.; Fridman, A. Applied plasma medicine. Plasma Process. Polym. 2008, 5, 503-533. [CrossRef]

17. Weltmann, K.D.; von Woedtke, T. Basic requirements for plasma sources in medicine. Eur. Phys. J. Appl. Phys. 2011, 55, 13807. [CrossRef]

18. Kong, M.G.; Kroesen, G.; Morfill, G.; Nosenko, T.; Shimizu, T.; van Dijk, J.; Zimmermann, J.L. Plasma medicine: An introductory review. New J. Phys. 2009, 11, 115012. [CrossRef]

19. Laroussi, M.; Fridman, A.; Satava, R.M. Plasma medicine. Plasma Process. Polym. 2008, 5, 501-502. [CrossRef]

20. Morfill, G.E.; Kong, M.G.; Zimmermann, J.L. Focus on plasma medicine. New J. Phys. 2009, 11, 115011. [CrossRef] 
21. Metelmann, H.R.; Seebauer, C.; Miller, V.; Fridman, A.; Bauer, G.; Graves, D.B.; Pouvesle, J.M.; Rutkowski, R.; Schuster, M.; Bekeschus, S.; et al. Clinical experience with cold plasma in the treatment of locally advanced head and neck cancer. Clin. Plasma Med. 2018, 9, 6-13. [CrossRef]

22. Kieft, I.E.; Broers, J.L.V.; Caubet-Hilloutou, V.; Slaaf, D.W.; Ramaekers, F.C.S.; Stoffels, E. Electric discharge plasmas influence attachment of cultured cho k1 cells. Bioelectromagnetics 2004, 25, 362-368. [CrossRef] [PubMed]

23. Vandamme, M.; Robert, E.; Pesnel, S.; Barbosa, E.; Dozias, S.; Sobilo, J.; Lerondel, S.; Le Pape, A.; Pouvesle, J.M. Antitumor effect of plasma treatment on $\mathrm{u} 87$ glioma xenografts: Preliminary results. Plasma Process. Polym. 2010, 7, 264-273. [CrossRef]

24. Mizuno, K.; Yonetamari, K.; Shirakawa, Y.; Akiyama, T.; Ono, R. Anti-tumor immune response induced by nanosecond pulsed streamer discharge in mice. J. Phys. D Appl. Phys. 2017, 50, 12LT01. [CrossRef]

25. Lin, A.; Truong, B.; Patel, S.; Kaushik, N.; Choi, E.H.; Fridman, G.; Fridman, A.; Miller, V. Nanosecond-pulsed DBD plasma-generated reactive oxygen species trigger immunogenic cell death in A549 lung carcinoma cells through intracellular oxidative stress. Int. J. Mol. Sci. 2017, 18, 966. [CrossRef] [PubMed]

26. Farkona, S.; Diamandis, E.P.; Blasutig, I.M. Cancer immunotherapy: The beginning of the end of cancer? BMC Med. 2016, 14, 73. [CrossRef] [PubMed]

27. Chen, D.S.; Mellman, I. Elements of cancer immunity and the cancer-immune set point. Nature 2017, 541, 321-330. [CrossRef] [PubMed]

28. Kirkwood, J.M.; Butterfield, L.H.; Tarhini, A.A.; Zarour, H.; Kalinski, P.; Ferrone, S. Immunotherapy of cancer in 2012. CA Cancer J. Clin. 2012, 62, 309-335. [CrossRef] [PubMed]

29. Topalian, S.L.; Weiner, G.J.; Pardoll, D.M. Cancer immunotherapy comes of age. J. Clin. Oncol. 2011, 29, 4828-4836. [CrossRef] [PubMed]

30. Okazaki, T.; Chikuma, S.; Iwai, Y.; Fagarasan, S.; Honjo, T. A rheostat for immune responses: The unique properties of PD-1 and their advantages for clinical application. Nat. Immunol. 2013, 14, 1212-1218. [CrossRef] [PubMed]

31. Radogna, F.; Diederich, M. Stress-induced cellular responses in immunogenic cell death: Implications for cancer immunotherapy. Biochem. Pharmacol. 2018, 153, 12-23. [CrossRef] [PubMed]

32. Hernandez, C.; Huebener, P.; Schwabe, R.F. Damage-associated molecular patterns in cancer: A double-edged sword. Oncogene 2016, 35, 5931-5941. [CrossRef] [PubMed]

33. Miller, V.; Lin, A.; Kako, F.; Gabunia, K.; Kelemen, S.; Brettschneider, J.; Fridman, G.; Fridman, A.; Autieri, M. Microsecond-pulsed dielectric barrier discharge plasma stimulation of tissue macrophages for treatment of peripheral vascular disease. Phys. Plasmas 2015, 22, 122005. [CrossRef] [PubMed]

34. Miller, V.; Lin, A.; Fridman, A. Why target immune cells for plasma treatment of cancer. Plasma Chem. Plasma Process. 2016, 36, 259-268. [CrossRef]

35. Lin, A.; Truong, B.; Pappas, A.; Kirifides, L.; Oubarri, A.; Chen, S.Y.; Lin, S.J.; Dobrynin, D.; Fridman, G.; Fridman, A.; et al. Uniform nanosecond pulsed dielectric barrier discharge plasma enhances anti-tumor effects by induction of immunogenic cell death in tumors and stimulation of macrophages. Plasma Process. Polym. 2015, 12, 1392-1399. [CrossRef]

36. Kaushik, N.K.; Kaushik, N.; Min, B.; Choi, K.H.; Hong, Y.J.; Miller, V.; Fridman, A.; Choi, E.H. Cytotoxic macrophage-released tumour necrosis factor-alpha (TNF-alpha) as a killing mechanism for cancer cell death after cold plasma activation. J. Phys. D Appl. Phys. 2016, 49, 084001. [CrossRef]

37. Bekeschus, S.; Favia, P.; Robert, E.; von Woedtke, T. White paper on plasma for medicine and hygiene: Future in plasma health sciences. Plasma Process. Polym. 2018. [CrossRef]

38. Bekeschus, S.; Rodder, K.; Schmidt, A.; Stope, M.B.; von Woedtke, T.; Miller, V.; Fridman, A.; Weltmann, K.D.; Masur, K.; Metelmann, H.R.; et al. Cold physical plasma selects for specific thelper cell subsets with distinct cells surface markers in a caspase-dependent and NF-kappa B-independent manner. Plasma Process. Polym. 2016, 13, 1144-1150. [CrossRef]

39. Bekeschus, S.; Moritz, J.; Schmidt, A.; Wende, K. Redox regulation of leukocyte-derived microparticle release and protein content in response to cold physical plasma-derived oxidants. Clin. Plasma Med. 2017, 7, 24-35. [CrossRef]

40. Torii, K.; Yamada, S.; Nakamura, K.; Tanaka, H.; Kajiyama, H.; Tanahashi, K.; Iwata, N.; Kanda, M.; Kobayashi, D.; Tanaka, C.; et al. Effectiveness of plasma treatment on gastric cancer cells. Gastric Cancer 2014, 18, 635-643. [CrossRef] [PubMed] 
41. Hattori, N.; Yamada, S.; Torii, K.; Takeda, S.; Nakamura, K.; Tanaka, H.; Kajiyama, H.; Kanda, M.; Fujii, T.; Nakayama, G.; et al. Effectiveness of plasma treatment on pancreatic cancer cells. Int. J. Oncol. 2015, 47, 1655-1662. [CrossRef] [PubMed]

42. Tanaka, H.; Mizuno, M.; Ishikawa, K.; Nakamura, K.; Utsumi, F.; Kajiyama, H.; Kano, H.; Maruyama, S.; Kikkawa, F.; Hori, M. Cell survival and proliferation signaling pathways are downregulated by plasma-activated medium in glioblastoma brain tumor cells. Plasma Med. 2014, 2, 207-220. [CrossRef]

43. Adachi, T.; Tanaka, H.; Nonomura, S.; Hara, H.; Kondo, S.I.; Hori, M. Plasma-activated medium induces A549 cell injury via a spiral apoptotic cascade involving the mitochondrial-nuclear network. Free Radical Biol. Med. 2014, 79, 28-44. [CrossRef] [PubMed]

44. Tanaka, H.; Mizuno, M.; Ishikawa, K.; Takeda, K.; Nakamura, K.; Utsumi, F.; Kajiyama, H.; Kano, H.; Okazaki, Y.; Toyokuni, S.; et al. Plasma medical science for cancer therapy: Toward cancer therapy using nonthermal atmospheric pressure plasma. IEEE Trans. Plasma Sci. 2014, 42, 3760-3764. [CrossRef]

45. Yan, D.Y.; Xiao, H.J.; Zhu, W.; Nourmohammadi, N.; Zhang, L.G.; Bian, K.; Keidar, M. The role of aquaporins in the anti-glioblastoma capacity of the cold plasma-stimulated medium. J. Phys. D Appl. Phys. 2017, 50, 055401. [CrossRef]

46. Takeda, S.; Yamada, S.; Hattori, N.; Nakamura, K.; Tanaka, H.; Kajiyama, H.; Kanda, M.; Kobayashi, D.; Tanaka, C.; Fujii, T.; et al. Intraperitoneal administration of plasma-activated medium: Proposal of a novel treatment option for peritoneal metastasis from gastric cancer. Ann. Surg. Oncol. 2017, 24, 1188-1194. [CrossRef] [PubMed]

47. Nakamura, K.; Peng, Y.; Utsumi, F.; Tanaka, H.; Mizuno, M.; Toyokuni, S.; Hori, M.; Kikkawa, F.; Kajiyama, H. Novel intraperitoneal treatment with non-thermal plasma-activated medium inhibits metastatic potential of ovarian cancer cells. Sci. Rep. 2017, 7, 6085. [CrossRef] [PubMed]

48. Sato, Y.; Yamada, S.; Takeda, S.; Hattori, N.; Nakamura, K.; Tanaka, H.; Mizuno, M.; Hori, M.; Kodera, Y. Effect of plasma-activated lactated ringer's solution on pancreatic cancer cells in vitro and in vivo. Ann. Surg. Oncol. 2018, 25, 299-307. [CrossRef] [PubMed]

49. Tanaka, H.; Nakamura, K.; Mizuno, M.; Ishikawa, K.; Takeda, K.; Kajiyama, H.; Utsumi, F.; Kikkawa, F.; Hori, M. Non-thermal atmospheric pressure plasma activates lactate in ringer's solution for anti-tumor effects. Sci. Rep. 2016, 6, 36282. [CrossRef] [PubMed]

(C) 2018 by the authors. Licensee MDPI, Basel, Switzerland. This article is an open access article distributed under the terms and conditions of the Creative Commons Attribution (CC BY) license (http:/ / creativecommons.org/licenses/by/4.0/). 